\title{
STRATEGI PENGEMBANGAN AGRIBISNIS KOPI ROBUSTA DI KABUPATEN SOLOK
}

\section{Development Strategy of Robusta Coffee Agribusiness in District of Solok}

\author{
Rika Hariance, Rudi Febriamansyah, dan Faidil Tanjung \\ Dosen Pada Program Studi Agribisnis Jurusan Sosial Ekonomi \\ Fakultas Pertanian Universitas Andalas \\ rikahariance@gmail.com
}

\begin{abstract}
The purpose of this study is to formulate agribusiness development strategy of robusta coffee. By taking the area productian as a consideration, this study chose three areas as the research site purposively which are Sub district Tigo Lurah, Pantai Cermin and $X$ Koto Singkarak. The data for this this study were analized qualitatively by using SWOT and QSPM analysis. Based on SWOT and QSPM analysis, the main strategy in development of agribusiness robusta coffee is improving competitiveness through quality improvement of robusta coffe and its other processed products. Expectantly this strategy could overcome the main problem of agribusiness robusta coffe in Solok district such as low quality and low competitiveness of robusta coffe in this area. Moreover, the alternatif policies that could be established based on the stategy above are (1) rehabilitating robusta coffe plantations in order to increase the production, (2) replanting the unproductive robusta coffee trees, (3) planting the new robusta coffe trees, and (4) maintaining the quality by apllying the recommendation of cultivation technique and post production.
\end{abstract}

Key word: Development strategy, Agribusiness, Robusta coffee

\section{PENDAHULUAN}

Pembangunan daerah pada dasarnya merupakan bagian internal dari pembangunan nasional dan tidak dapat dipisahkan dari pola pembangunan nasional yang bertujuan untuk mewujudkan masyarakat adil dan merata di seluruh wilayah tanah air. Dengan demikian dalam pelaksanaan pembangunan tersebut memerlukan suatu perencanaan yang strategis dan didukung oleh ketersediaan dana serta partisipasi masyarakat sebagai subyek pembangunan untuk meningkatkan pemerataan pertumbuhan dan pembangunan di segala bidang. Todaro (2000) menyatakan bahwa pembangunan mengandung nilainilai hakiki yang berhubungan dengan kebutuhan masyarakat yang paling mendasar, yang terdapat pada hampir semua masyarakat/kultur di segala zaman. Nilai-nilai tersebut adalah kebutuhan hidup, harga diri dan kebebasan. 
Menurut Swasono (2002), sektor pertanian menjadi pilihan penting karena posisinya yang berdasar sumber-sumber sendiri (domestic resources based) dan bertitik sentral pada rakyat dengan sekaligus mengutamakan kepentingan rakyat. Domestic Resources Based strategy akan lebih mampu menjamin kemandirian Industri dalam negeri, agar tidak kelewat tergantung pada kebutuhan akan komponen luar negeri sebagai elemen ketergantungan, kandungan impor produk industri dalam negeri menjadi minimal. Berbagai hasil pembangunan terutama yang berkaitan dengan upaya pemberdayaan masyarakat perkebunan seperti yang diharapkan pada pengembangan perkebunan rakyat baik melalui pola PIR, UPP maupun pola swadaya petani perkebunan, baru menikmati pendapatan produksi (off farm) yang umumnya mempunyai margin pendapatan yang lebih besar, lebih banyak dinikmati oleh pengusaha besar, tetapi belum banyak dinikmati oleh petani. Tantangan perkebunan kedepan adalah peningkatan daya saing bukan saja negara produsen di wilayah tropis, tetapi juga dengan negara maju yang terus menerus melakukan penelitian untuk menghasilkan produk perkebunan. (Admaizon, 2004).

Sampai pada tahun 2004 Indonesia mampu menghasilkan 675 ribu ton kopi yang $61 \%$ nya diekspor dan sisanya digunakan untuk memenuhi kebutuhan dalam negeri baik untuk konsumsi maupun untuk carry over stocks oleh pedagang dan eksportir, sebagai cadangan bila terjadi gagal panen (Kustiari, 2007). Untuk tahun 2010, Indonesia menargetkan akan mengekspor kopi sebanyak 662.338 ton setelah dikurangi dengan kebutuhan domestik untuk memenuhi pasar USA, Jepang, dan Eropa Barat (Dirjen Pengolahan dan Pemasaran Hasil Pertanian, 2007). Sementara itu, AEKI (2016) melaporkan bahwa volume ekspor kopi Indonesia rata-rata berkisar 350 ribu ton per tahun meliputi kopi robusta $(85 \%)$ dan arabika $(15 \%)$

Di Sumatera Barat tercatat terdapat sebanyak 42.565 Ha lahan perkebunan kopi dengan total produksi sebanyak 32.559 ton (Dirjen Perkebunan, 2014). Perkebunan kopi di Sumatera Barat tersebar hampir diseluruh Kabupaten/Kota salah satunya Kabupaten Solok. Berdasarkan hasil pra survey yang dilakukan diketahui bahwa petani di kabupaten Solok lebih banyak mengusahakan kopi robusta dibandingkan kopi arabika. Walaupun harga kopi arabika lebih tinggi dari pada kopi robusta, namun petani lebih senang mengusahakan kopi robusta, sebab kopi jenis ini lebih resisten terhadap hama penyakit, lebih mudah perawatannya, dan permintaan terhadap kopi ini juga lebih banyak dibandingkan dengan kopi arabika(AEKI 2016). Oleh karena itu diperlukan suatu strategi yang baik, agar perkebunan rakyat kopi robusta dapat memberikan manfaat yang besar bagi peningkatan kesejahteraan rakyat pekebun kopi robusta.

Dalam usaha pengembangan agribisnis kopi selain subsistem yang menunjang agribisnis, banyak faktor lainnya yang harus dipertimbangkan 
disamping banyaknya peluang dan tantangan yang dihadapi. Peluang dan tantangan dapat dilihat dari tersedianya lahan yang cukup luas, sumberdaya manusia sebagai tenaga kerja, terdapatnya pasar lokal, regional dalam propinsi maupun luar propinsi, dan pasar internasional, adanya dukungan pemerintah daerah dan tersedianya fasilitas penghubung dan kelembagaan penunjang lainnya.

Hal ini menunjukkan bahwa peluang untuk pengembangan budidaya maupun pengembangan agribisnis juga masih sangat potensial. Dalam rangka pengembangan agribisnis kopi robusta di Kabupaten Solok diperlukan keterlibatan semua pihak, karena pengembangan suatu agribisnis merupakan suatu sistem terdiri dari subsistem penyedia saprodi, subsistem produksi (onfarm/ usahatani), subsistem off-farm yaitu pemasaran dan pengolahan, dan subsistem penunjang berupa lembaga pemerintah sebagai pengambil kebijakan, lembaga keuangan maupun lembaga penelitian.

Dari latar belakang dan perumusan masalah diatas, maka dapat dirumuskan beberapa permasalahan sebagai berikut: Strategi apa yang tepat untuk dilakukan dalam usaha pengembangan agribisnis kopi robusta di Kabupaten Solok?. Berdasarkan perumusan masalah tersebut maka dilakukan penelitian tentang Strategi Pengembangan Agribisnis Kopi Robusta di Kabupaten Solok. Adapun tujuan dari penelitian ini adalah untuk merumuskan strategi pengembangan agribisnis Kopi Robusta di Kabupaten Solok.

\section{METODOLOGI PENELITIAN}

\section{Lokasi Penelitian}

Penelitian ini dilaksanakan pada wilayah Kabupaten Solok, yaitu Kecamatan-kecamatan yang memiliki luas tanam kopi robusta paling luas di Kabupaten Solok. Data Dinas Kehutanan dan Perkebunan Kab. Solok (2010) menunjukkan tiga kecamatan yang memiliki luas tanam terluas, yaitu Kecamatan Tigo Lurah, Pantai Cermin dan X Koto Singkarak.

\section{Populasi dan Sampel}

Jumlah petani yang melakukan usahatani kopi robusta di kabupaten Solok adalah sebanyak 6. 910 petani, yang tersebar pada 14 Kecamatan (Dinas Kehutanan dan Perkebunan Kab. Solok, 2010). Karena wilayah penelitian yang dipilih adalah Kecamatan Tigo Lurah, Pantai Cermin dan X Koto Singkarak maka yang menjadi populasi adalah petani di wilayah tersebut yaitu sebanyak 1.735 petani, sampel diambil sebanyak $5 \%$ dari jumlah populasi tersebut. Sehingga sampel dari penelitian ini menjadi sebanyak 86 orang, yang nanti akan dipilih secara proposional (Propotionate Random Sampling). Oleh karena itu maka untuk Kecamatan Tigo Lurah diambil sebanyak 19 orang sampel, Kecamatan 
Pantai Cermin sebanyak 39 orang sampel, dan Kecamatan X Koto Singkarak 28 orang sampel.

\section{Sumber Data dan Teknik Pengumpulan Data}

Untuk merumuskan strategi yang tepat untuk pengembangan agribisnis kopi robusta di Kabupaten Solok, data yang dikumpulkan dibagi menjadi dua bagian yaitu faktor internal dan faktor eksternal yang mempengaruhi pengembangan kopi robusta di Kabupaten Solok. Data diperoleh melalui wawancara yang mendalam dengan informan kunci berupa kekuatan, kelemahan, tantangan dan ancaman yang dimiliki. Informan kunci disini adalah pelaku Sistem Agribisnis Kopi Robusta sebagai pihak internal yaitu terdiri dari pedagang saprodi pada subsistem hulu, petani kopi robusta pada subsistem usahatani, pedagang pengumpul pada subsistem pemasaran, industri pengolahan kopi pada subsistem pengolahan, Dinas Perkebunan dan Kehutanan Kabupaten Solok, Bappeda Kabupaten Solok, Dinas Koperasi Usaha Kecil dan Menengah dan Perindustrian Perdagangan Kabupaten Solok, dan Perbankan di Lingkungan Kabupaten Solok pada subsistem penunjang dari agribisnis kopi robusta di Kabupaten Solok. Kemudian faktor selain faktor tersebut diatas termasuk kedalam faktor eksternal yaitu Kebijakan Pemerintah Pusat dan Daerah Sumatera Barat terkait dengan otonomi daerah, dan perdagangan kopi robusta nasional dan internasional.

\section{Metode Analisis Data}

Menurut Rangkuti (2006), langkah-langkah yang dilakukan dalam perumusan strategi adalah sebagai berikut:

\section{Tahap Pengumpulan data}

Tahap ini pada dasarnya tidak hanya sekedar pengumpulan data, tetapi juga merupakan suatu kegiatan pengklasifikasian dan pra analisis. Pada tahap ini data dapat dibedakan menjadi dua yaitu data internal dan eksternal. Model yang digunakan pada tahap ini adalah analisis faktor internal dan eksternal dengan menyusun pada suatu tabel yaitu tabel IFAS (Internal Factor Analisys Summary).

\section{Tahap Analisis}

Setelah semua data yang mempengaruhi pengembangan agribisnis kopi robusta dikumpulkan, dilanjutkan kepada tahap analisis melalui model perumusan strategi dengan matriks SWOT. 
Tabel 1 Matriks Analisis Faktor Internal dan Eksternal (IFA/EFA)

\begin{tabular}{llll}
\hline Uraian Faktor Internal dan Eksternal & Bobot & Ratting & Skor \\
\hline Faktor Internal & & \\
a. Kekuatan & & \\
b. Kelemahan & & \\
\hline \multicolumn{2}{l}{ Total Skor Faktor Internal } & & \\
\hline
\end{tabular}

Faktor Eksternal

a. Peluang

b. Ancaman

Total Skor Faktor Eksternal

\section{Tahap Pencocokan Strategi Pengembangan Agribsinis Kopi Robusta}

Dari matriks SWOT akan didapatkan 4 kemungkinan alternatif strategi seperti yang diperlihatkan oleh gambar berikut ini:

\section{Tabel 2 Matriks SWOT}

\begin{tabular}{|c|c|c|}
\hline IFA/EFA & STRENGHTS (S) & WEAKNES (W) \\
\hline & Strategi SO & Strategi WO \\
\hline OPPORTUNITIES (O) & $\begin{array}{l}\text { Menciptakan strategi yang } \\
\text { menggunakan kekuatan } \\
\text { untuk memanfaatkan } \\
\text { peluang jika berada pada } \\
\text { kuadran I }\end{array}$ & $\begin{array}{l}\text { Menciptakan strategi yang } \\
\text { meminimalkan kelemahan } \\
\text { untuk memanfaatkan } \\
\text { peluang. Digunakan jika } \\
\text { berada pada kuadran III }\end{array}$ \\
\hline & $\begin{array}{l}\text { Strategi ST } \\
\end{array}$ & Strategi WT \\
\hline TREATHS (T) & $\begin{array}{l}\text { Menciptakan strategi yang } \\
\text { menggunakan kekuatan } \\
\text { untuk mengatasi ancaman. } \\
\text { Digunakan jika berada pada } \\
\text { kuadran II }\end{array}$ & $\begin{array}{c}\text { Menciptakan strategi yang } \\
\text { meminimalkan kelemahan } \\
\text { dan menghindari ancaman. } \\
\text { Digunakan jika berada pada } \\
\text { kuadran IV }\end{array}$ \\
\hline
\end{tabular}

\section{Tahap Pengambilan Keputusan Strategi Pengembangan}

Setelah dilakukan pencocokan terhadap faktor internal dan eksternal agribisnis kopi robusta di Kabupaten Solok dilakukan pengambilan keputusan untuk menetapkan strategi utama dalam Pengembangan Agribisnis Kopi Robusta di Kabupaten Solok melalui alat analisa QSPM (Quantitative Strtaegic Planning Matrix). Teknik ini secara objektif mengindikasikan alternative strategi mana yang terbaik dari pilihan strategi yang ada. QSPM manggunakan input dari tahap 1 (matriks IE) dan hasil pencocokan dari tahap 2 (SWOT). Adapun langkah yang dapat dilakukan untuk membuat matriks QSPM adalah sebagai berikut: (a) Membuat daftar faktor kunci internal dan eksternal, (b) Memberikan bobot untuk masing-masing faktor kunci, (c) Memasukkan alternatif strategi dari tahap pencocokan, (d) Menentukan nilai daya tarik (Atractiveness ScoresAS) dari 1 = Tidak Menarik, 2 = agak menarik, 3 = cukup menarik dan $4=$ 
Menarik, (d) Hitung nilai total daya tarik (Total Atractiveness Scores - TAS), (e) Hitung Penjumlahan TAS , dan (f) Pilih Strategi dengan nilai TAS paling tinggi

\section{HASIL DAN PEMBAHASAN}

\section{Gambaran Umum Daerah Penelitian}

Kabupaten Solok adalah sebuah kabupaten di provinsi Sumatera Barat. Ibu kotanya ialah Arosuka. Luas wilayah Kabupaten Solok 378.800 Ha atau $3.738,00 \mathrm{~km}$ terdiri dari 14 Kecamatan dan 74 Nagari. Secara geografis letak

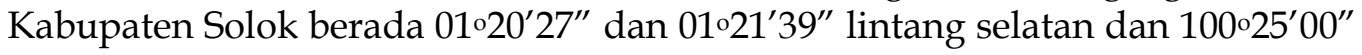
dan 100'33'43" bujur timur. Topografi daerah sangat bervariasi antara dataran, lembah dan bukit-bukit dengan ketinggian antara 329 meter -1.458 meter di atas permukaan laut. Kabupaten Solok berbatas dengan: (a) Sebelah Selatan dengan Kabupaten Solok Selatan, (b) Sebelah Utara dengan Kabupaten Tanah Datar, (0 Sebelah Barat dengan Kota Padang dan Kabupaten Pesisir Selatan, dan (d) Sebelah Timur dengan Sawah Lunto dan Kabupaten Sawahlunto Sijunjung.

Kabupaten Solok terletak pada posisi yang strategis, karena berada pada jalur lintas Sumatera dan berbatasan dengan Kota Padang. Dilihat dari komposisi pemanfaatan lahan, sebanyak 38, 90 \% wilayah Kabupaten Solok masih berstatus hutan negara dan 16,02 \% berstatus hutan rakyat sedangkan yang diolah rakyat untuk Ladang/kebun sebanyak 9,88 \% dan yang dikelola perusahaan perkebunan mencapai 2,08 \%. Luas lahan yang diusahakan untuk tanaman perkebunan rakyat di kabupaten Solok adalah seluas $36.953 \mathrm{Ha}$, dari luas lahan tersebut 20,83 \% atau 7.700,60 Ha diusahakan untuk tanaman perkebunan kopi robusta.

Kabupaten Solok beriklim tropis dengan temperatur berada pada kisaran 12 - $32{ }^{\circ} \mathrm{C}$, kelembaban udara mencapai $80 \%$ dan curah hujan sebanyak 268,93 $\mathrm{mm} / \mathrm{th}$, sedangkan kecepatan angin mencapai 0,67 Knot. Kabupaten Solok berada pada ketinggian tempat 329 - 1.458 meter diatas permukaan laut (Profil Kab. Solok, 2007). Kondisi iklim yang seperti ini merupakan iklim yang cocok untuk tanaman kopi robusta.

Sektor pertanian masih memberikan kontribusi paling besar dalam PDRB Kabupaten Solok. Sektor pertanian yang dimaksudkan disini adalah sektor yang menghasilkan produk primer berupa tanaman hortikultura, pangan, perkebunan, perikanan dan perternakan. Sementara industri pegolahan baru memberikan kontribusi sebesar 7,81 \% dari PDRB Kabupaten Solok, ini memperlihatkan bahwa masih terdapat ketimpangan produktivitas sektoral yang cukup tinggi di Kabupaten Solok. Sektor pertanian termasuk perkebunan robusta masih merupakan sektor yang diusahakan oleh rakyat dalam skala kecil, ketergantungan yang besar tetrhadap sektor ini dalam jangka panjang akan berdampak dalam kesejahteraan masyarakat. Untuk itu diperlukan upaya 
meningkatkan sektor industri pengolahan agar dapat meningkatkan serapan tenaga kerja diluar sektor pertanian yang berdampak pada peningkatan kesejahteraan masyarakat.

\section{Keadaan Perkebunan}

Pertanian di Kabupaten Solok dibagi kedalam lima sub sektor yaitu : tanaman pangan, hortikultura, perkebunan, perikanan dan peternakan. Masingmasing subsektor memiliki komoditas unggulan yang mempunyai prospek perkembangan yang baik dimasa yang akan datang. Pada subsektor perkebunan jenis tanaman yang potensial di Kabupaten Solok antara lain Teh, Kopi, Coklat (Kakao), karet dan cengkeh. Komoditas yang telah dikelola oleh perkebunan besar adalah teh, kopi dan kakao. Berdasarkan data Dinas Kehutanan dan Perkebunan dari tahun 2006 - 2008, rata-rata jumlah produksi masing-masing komoditi perkebunan rakyat adalah kopi 4.656 ton, kakao 397 ton, karet 1.019 ton, cengkeh 315 ton dan teh 984 ton. Sentra perkebunan kopi robusta terletak pada kecamatan Pantai Cermin, Tigo Lurah dan X Koto Singkarak.

\section{Profil Responden}

Dari 86 orang petani responden yang diwawancarai didapatkan gambaran profil petani kopi robusta pada tabel berikut:

\section{Tabel 3 Profil Responden Kopi Robusta di Kabupaten Solok}

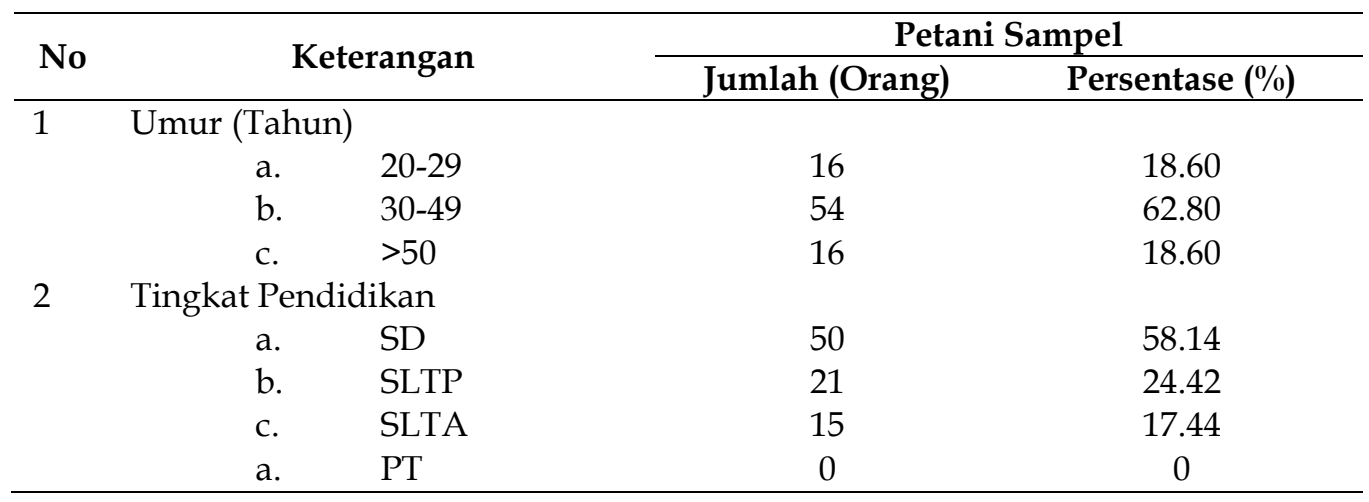

Dilihat dari angka tersebut $62.80 \%$ petani responden termasuk kedalam angkatan kerja produktif, ini merupakan usia produktif maka kemampuan untuk menerima pengetahuan dan inovasi baru tentang agribisnis kopi robusta lebih baik dari angkatan kerja yang tidak produktif. Kemudian dilihat dari tingkat pendidikan, $58.14 \%$ petani kopi robusta memiliki tingkat pendidikan SD, $24.42 \%$ petani berpendidikan SLTP dan hanya $17.44 \%$ petani berpendidikan SLTA. Dilihat dari persentase tersebut. Lebih dari 50\% petani berpendidikan SD ini memperlihatkan bahwa tingkat pendidikan rata-rata petani kopi robusta di Kabupaten Solok masih rendah. 


\section{Identifikasi Faktor Internal dan Eksternal}

Berdasarkan kepada subsistem dalam agribisnis, maka faktor internal dan eksternal dari agribisnis kopi robusta dapat dilihat pada tabel 4 di bawah ini.

\section{Tabel 4 Faktor Internal dan Eksternal Agribisnis Kopi Robusta di Kabupaten Solok}

\begin{tabular}{|c|c|c|c|c|}
\hline \multirow{2}{*}{ Identifikasi Kondisi Subsistem } & \multicolumn{2}{|c|}{ Faktor Internal } & \multicolumn{2}{|c|}{ Faktor Eksternal } \\
\hline & $\mathbf{S}$ & $\mathbf{W}$ & $\mathrm{O}$ & $\mathbf{T}$ \\
\hline \multicolumn{5}{|l|}{$\begin{array}{l} \\
\text { SubSistem Hulu }\end{array}$} \\
\hline $\begin{array}{l}\text { Belum adanya kegiatan Pembibitan melalui penangkaran } \\
\text { bibit }\end{array}$ & & $\sqrt{ }$ & & \\
\hline $\begin{array}{l}\text { Adanya Lembaga Pusat Penelitian Kopi dan Kakao di } \\
\text { Jember Untuk Pusat Riset Bibit Unggul }\end{array}$ & & & $\sqrt{ }$ & \\
\hline $\begin{array}{l}\text { Tersedianya Pupuk bersubsidi yang dapat diperoleh oleh } \\
\text { Petani melalui Dinas kehutanan dan perkebunan Kab. } \\
\text { Solok }\end{array}$ & $\sqrt{ }$ & & & \\
\hline \multicolumn{5}{|l|}{$\begin{array}{ll} & \text { SubSistem Usahatani } \\
\end{array}$} \\
\hline $\begin{array}{l}\text { Luas Lahan Usahatani Kopi Robusta Yang Tersedia Cukup } \\
\text { Luas Untuk Kegiatan Pengembangan }\end{array}$ & $\sqrt{ }$ & & & \\
\hline Kondisi Agroklimat dan geomorfologi yang mendukung & & & $\sqrt{ }$ & \\
\hline Umur Petani Yang Masih Produktif & $\sqrt{ }$ & & & \\
\hline Budidaya yang masih belum intensif & & $\sqrt{ }$ & & \\
\hline Kualitas Kopi Robusta yang Masih Rendah & & $\sqrt{ }$ & & \\
\hline Tingkat Adopsi Iptek Yang Masih Rendah & & $\sqrt{ }$ & & \\
\hline Tingkat Pendidikan Petani yang masih rendah & & $\sqrt{ }$ & & \\
\hline
\end{tabular}

\section{Subsistem Pemasaran}

Sifat Pasar Yang terbuka Mengakibatkan tumbuhnya persaingan dari produk lain yang sejenis

Produk yang dihasilkan tidak memiliki daya saing karena kualitasnya yang masih rendah

Belum terjadi jaringan kerjasama antara lembaga yang ada dalam subsistem agribisnis kopi robusta terutama antara petani dan pedagang

Pasar Lokal, Domestik, dan Internasional yang terbuka luas

\section{Subsistem Pengolahan Pasca Panen}

Kualitas Beras Kopi Yang dihasilkan masih rendah Belum ada jaringan kerjasama antar lembaga dalam sistem agribisnis kopi robusta untuk pengolahan pasca panen kopi robusta

Adopsi Iptek yang masih rendah

\section{Subsistem Penunjang}

\begin{tabular}{l}
\hline Akses ke modal usaha masih kurang \\
$\begin{array}{l}\text { Fungsi PPL masih belum maksimal } \\
\text { Adanya Kebijakan Pemerintah Daerah untuk }\end{array}$ \\
mengembangkan Ekonomi Kerakyatan
\end{tabular}




\section{Proses Pembobotan Faktor Internal dan Eksternal}

Dalam rangka menyusun alternatif strategi agribisnis kopi robusta di Kabupaten Solok, perlu dilakukan terlebih dahulu identifikasi terhadap faktor internal dan faktor eksternal dalam agribisnis kopi robusta ini. Hal ini dilakukan agar alternatif kebijakan yang dihasilkan mampu memberikan solusi dalam menghadapi permasalahan yang dihadapi dalam agribisnis kopi robusta.

\section{Faktor Internal}

Karena strategi ini bertujuan untuk pengembangan agribisnis kopi robusta maka yang akan menjadi fokus dalam pengembangan adalah sistem agribisnis kopi robusta yang akan diidentifikasi kekuatan dan kelemahan yang ada di dalamnya. Faktor internal diidentifikasi sebagai hal-hal yang dapat dikendalikan oleh sistem agribisnis kopi robusta.

\section{Faktor Eksternal}

Faktor eksternal yaitu hal-hal yang tidak dapat dikendalikan oleh petani kopi robusta yang terdiri dari peluang dan ancaman dalam pengembangan agribisnis kopi robusta di Kabupaten Solok. Pihak eksternal adalah Pemerintah pusat yaitu Departemen Pertanian, Dinas Perkebunan dan kehutanan Sumatera Barat, BAPPEDA Sumatera Barat, konsumen dan pesaing. Faktor eksternal yang diidentifikasi berupa kebijakan pemerintah pusat, kodisi pesaing, pasar domestik, regional dan global, kondisi politik daerah, dan faktor eksternal lainnya yang memberikan peluang dan ancaman bagi pengembangan agribisnis kopi robusta. 
Tabel 5 Internal Eksternal Faktor Analysis Sumary (Analisis Faktor Internal dan Eksternal) Strategi Pengembangan Agribisnis Kopi Robusta di Kabupaten Solok

\begin{tabular}{|c|c|c|c|}
\hline Faktor - Faktor Strategis Internal & Bobot & Ratting & $\begin{array}{c}\text { Skor } \\
\text { Terbobot }\end{array}$ \\
\hline \multicolumn{4}{|l|}{ Kekuatan } \\
\hline a Luas Lahan yang tersedia & 0.15 & 4 & 0.60 \\
\hline b Umur Petani Yang masih Produktif & 0.10 & 4 & 0.40 \\
\hline c Adanya Kelembagaan Kelompok tani & 0.05 & 3 & 0.10 \\
\hline $\begin{array}{l}\text { debijakan Pemerintah Daerah untuk } \\
\text { mengembangkan Ekonomi Kerakyatan }\end{array}$ & 0.10 & 3 & 0.20 \\
\hline \multicolumn{4}{|l|}{ e Tersedianya Pupuk Bersubsidi } \\
\hline & 0.10 & 4 & 0.40 \\
\hline Sub Total & & & 1.70 \\
\hline \multicolumn{4}{|l|}{ Kelemahan } \\
\hline $\begin{array}{l}\text { Budidaya kopi robusta yang masih belum } \\
\text { intensif dan Produktifitas rendah }\end{array}$ & 0.10 & 2 & 0.20 \\
\hline b Tingkat pendidikan petani yang rendah & & & \\
\hline c Tingkat adopsi Iptek masih rendah & 0.10 & 2 & 0.20 \\
\hline d Akses ke modal usaha masih kurang & 0.05 & 2 & 0.10 \\
\hline e Kualitas kopi robusta masih rendah & 0.05 & 1 & 0.05 \\
\hline f Fungsi PPL belum maksimal & 0.05 & 1 & 0.05 \\
\hline \multirow[t]{2}{*}{$\mathrm{g} \begin{array}{l}\text { Belum terjadi jaringan kerjasama antar } \\
\text { lembaga }\end{array}$} & 0.10 & 2 & 0.20 \\
\hline & 0.05 & 2 & 0.10 \\
\hline Sub Total & & & 0.90 \\
\hline Jumlah & 1.00 & & 2.60 \\
\hline \multicolumn{4}{|l|}{ Peluang } \\
\hline a Perekonomian daerah dan nasional & 0.10 & 2 & 0.30 \\
\hline b Otonomi Daerah & 0.15 & 2 & 0.30 \\
\hline $\begin{array}{l}\text { Pasar Lokal, Domestik dan Internasional Masih } \\
\text { terbuka luas }\end{array}$ & 0.20 & 4 & 0.80 \\
\hline $\begin{array}{l}\text { d Kondisi Agroklimat dan Geomorfologi yang } \\
\text { mendukung }\end{array}$ & 0.20 & 4 & 0.80 \\
\hline $\begin{array}{l}\text { e Adanya Lembaga Pusat Penelitian Kopi dan } \\
\text { Kakao Indonesia di Jember }\end{array}$ & 0.15 & 4 & 0.60 \\
\hline $\begin{array}{c}\text { Sub Total } \\
\end{array}$ & & & 2.80 \\
\hline \multicolumn{4}{|l|}{ Ancaman } \\
\hline $\begin{array}{l}\text { Sifat pasar yang terbuka mengakibatkan } \\
\text { persaingan produk dari daerah lain }\end{array}$ & 0.20 & 3 & 0.90 \\
\hline b Daya Saing yang masih lemah & 0.10 & 1 & 0.10 \\
\hline Sub Total & & & 1.00 \\
\hline Jumlah & 1.00 & & 3.20 \\
\hline
\end{tabular}

120 | Rika Hariance, Rudi Febriamansyah, dan Faidil Tanjung. Strategi .... 


\section{Tahap Analisis}

Setelah semua data yang mempengaruhi pengembangan agribisnis kopi robusta dikumpulkan, dilanjutkan kepada tahap analisis melalui model perumusan strategi dengan matriks SWOT.

\section{Tabel 6. Matriks SWOT Strategi Pengembangan Agribisnis Kopi Robusta di Kabupaten Solok.}

\begin{tabular}{|c|c|c|c|c|c|c|}
\hline & & & \multicolumn{4}{|c|}{ Faktor Internal } \\
\hline & & & & Kekuatan (Strenght) & & Kelemahan (Weakness) \\
\hline & & & & Luas Lahan yang tersedia & & $\begin{array}{l}\text { Budidaya kopi robusta yang masih belum } \\
\text { intensif dan Produktifitas rendah }\end{array}$ \\
\hline & & & 2 & Umur Petani Yang Masih Produktif & 2 & Tingkat pendidikan petani yang rendah \\
\hline & & & 3 & Adanya Kelembagaan Kelompok tani & 3 & Tingkat adopsi Iptek masih rendah \\
\hline & & & & $\begin{array}{l}\text { Kebijakan Pemerintah Daerah untuk } \\
\text { mengembangkan Ekonomi Kerakyatan }\end{array}$ & 4 & Akses ke modal usaha masih kurang \\
\hline & & & 5 & Tersedianya Pupuk Bersubsidi & 5 & Kualitas kopi robusta masih rendah \\
\hline & & & & & 6 & Fungsi PPL belum maksimal \\
\hline & & & & & 7 & $\begin{array}{l}\text { Belum terjadi jaringan kerjasama antar } \\
\text { lembaga }\end{array}$ \\
\hline & & Peluang (Opportunity) & & Strategi SO & & Strategi WO \\
\hline & 1 & $\begin{array}{l}\text { Tumbuhnya Perekonomian } \\
\text { daerah dan nasional }\end{array}$ & & Pengembangan suatu agribisnis terpadu & & $\begin{array}{l}\text { Mengembangkan organisasi petani sebagai } \\
\text { media untuk mengembangkan penge lolaan }\end{array}$ \\
\hline & 2 & Adanya Otonomi Daerah & $\mathrm{a}$ & penghasil kopi robusta. $\left(\mathrm{S}_{1,4} ; \mathrm{O}_{1,2,4}\right)$ & $\mathrm{a}$ & teknologi baru $\left(\mathrm{W}_{1,2,3,5,6} ; \mathrm{O}_{2,3}\right)$. \\
\hline 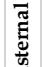 & 3 & $\begin{array}{l}\text { Pasar Lokal, Domestik dan } \\
\text { Internasional Masih terbuka luas }\end{array}$ & & Memfasilitasi dan merangsang investasi & & \\
\hline 产 & 4 & $\begin{array}{l}\text { Kondisi Agroklimat dan } \\
\text { Geomorfologi yang mendukung }\end{array}$ & $\mathrm{b}$ & $\begin{array}{l}\text { dalam membangun industri yang berbasis } \\
\text { pada kopi dan produk turunan lainnya }\left(\mathrm{S}_{4} \text {; }\right.\end{array}$ & $\mathrm{b}$ & $\begin{array}{l}\text { Mengembangkan networking pelaku-pelaku } \\
\text { lainnya dalam sistem agribisnis kopi robusta }\end{array}$ \\
\hline స్త్ర & 5 & $\begin{array}{l}\text { Adanya Lembaga Pusat Penelitian } \\
\text { Kopi dan Kakao di Jember }\end{array}$ & & $\mathrm{O}_{1,2}$ & & \\
\hline & & Ancaman (Threats) & & Strategi ST & & Strategi WT \\
\hline & 1 & $\begin{array}{l}\text { Sifat pasar yang terbuka } \\
\text { mengakibatkan persaingan } \\
\text { produk dari daerah lain }\end{array}$ & & $\begin{array}{l}\text { Pembangunan sistem dan usaha-usaha } \\
\text { pengolahan dan pemasaran produk kopi } \\
\text { didasarkan atas sumberdaya dan budaya }\end{array}$ & a & $\begin{array}{l}\text { Pembangunan sistem dan usaha-usaha } \\
\text { pengolahan dan pemasaran produk kopi } \\
\text { diarahkan pada peningkatan daya saing }\end{array}$ \\
\hline & 2 & Daya Saing yang masih lemah & & $\begin{array}{l}\text { lokal, pemanfaatan teknologi ramah } \\
\text { lingkungan, dan orientasi pasar }\left(\mathrm{S}_{1,2,3,4,5} ; \mathrm{T}_{1,2}\right) \text {. }\end{array}$ & & $\begin{array}{l}\text { melalui pembinaan perbaikan mutu dan } \\
\text { tampilan produk kopi dan olahannya } \\
\left(\mathrm{W}_{1,2,3,4,5} ; \mathrm{T}_{1,2}\right)\end{array}$ \\
\hline
\end{tabular}

\section{Tahap Pencocokan}

Setelah tahap analisis dilalui, proses selanjutnya adalah pengambilan keputusan dengan menggunakan strategi yang tepat. Dapat dilihat pada diagram analisis SWOT pada gambar berikut ini. 

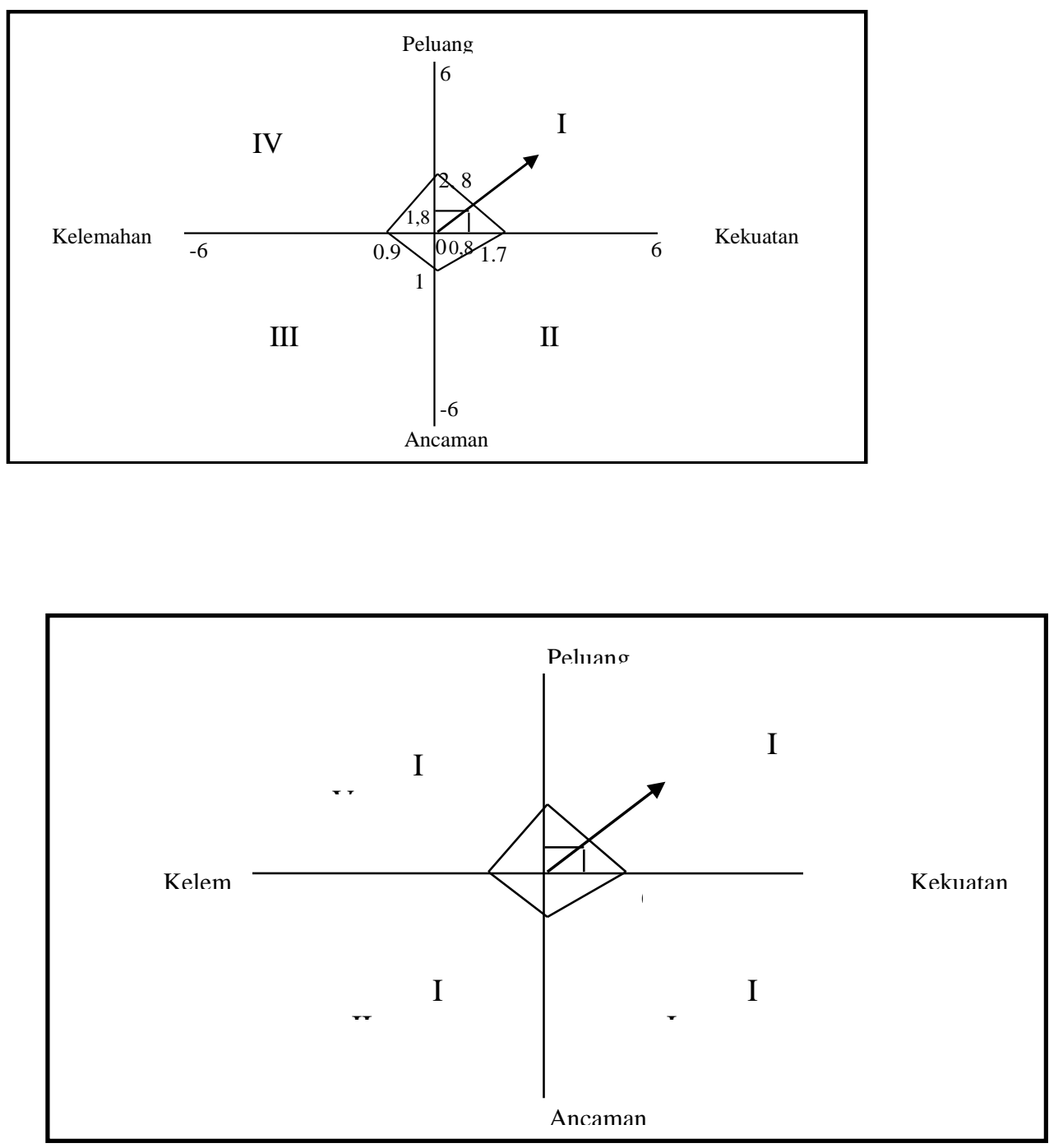

Gambar 3.

Diagram Analisis SWOT

Dari gambar diatas maka agribisnis kopi robusta berada pada kuadran I. Kudran ini merupakan situasi yang menguntungkan karena pengembangan agribisnis kopi robusta memiliki peluang dan kekuatan sehingga dapat memanfaatkan peluang yang ada. Strategi yang diterapkan dalam kondisi ini adalah mendukung kebijakan pertumbuhan yang agresif. Nilai pada kuadran diperoleh dari menghubungkan titik 0,8 pada kekuatan dan 1,8 peluang. 


\section{Tahap Pengambilan Keputusan}

Dari beberapa alternatif strategi yang diperoleh dari tahap pencocokan strategi pengembangan agribisnis kopi robusta di Kabupaten Solok diatas, diambil 3 alternatif strategi untuk dilakukan analisis untuk pengambilan keputusan strategi yang paling tepat dilaksanakan dalam rangka pengembangan agribisnis kopi robusta di Kabupaten Solok. Agribisnis kopi robusta di Kabupaten Solok berdasarkan analisis diatas memiliki masalah yang paling mendasar pada rendahnya mutu produk yang dihasilkan. Hal ini disebabkan karena pengelolaan usahatani yang masih belum intensif dan belum adanya pengembangan produk olahan kopi robusta yang dihasilkan selain produk beras kopi pada tingkat usahatani dan bubuk kopi pada tingkat usaha rumah tangga. Maka pengembangan agribisnis kopi robusta di Kabupaten Solok difokuskan pada perbaikan dan rehabilitasi kebun-kebun yang ada untuk meningkatkan hasil yang ada dan meningkatkan mutu hasil, sehingga produk yang dihasilkan dapat berdaya saing pada pasar domestik dan internasional, mengingat kopi robusta merupakan salah satu komoditi ekspor yang banyak diperdagangkan di pasar internasional.

Dari alternatif strategi yang diperoleh pada diagram SWOT diatas, maka tiga alternatif strategi yang tepat untuk dipilih menjadi strategi utama adalah

1. Pengembangan Agribisnis terpadu berbasis kopi di setiap wilayah utama penghasil kopi robusta

2. Pembangunan sistem agribisnis kopi didasarkan pada sumberdaya dan budaya lokal, pemanfaatan teknologi ramah lingkungan dan orientasi pasar

3. Pembangunan sistem agribisnis kopi robusta diarahkan pada peningkatan daya saing melalui pembinaan perbaikan mutu dan tampilan produk kopi robusta dan olahannya.

Ketiga alternative tersebut diolah dengan menggunakan matriks Quantitive Strategic Planning Matrix (QSPM). Seperti yang terlihat pada tabel dibawah ini. 
Tabel 10 Matriks QSPM Strategi Pengembangan Agribisnis Kopi Robusta di Kabupaten Solok

\begin{tabular}{|c|c|c|c|c|c|c|c|}
\hline \multirow{3}{*}{ Faktor Kunci } & \multirow{3}{*}{ Bobot } & \multicolumn{6}{|c|}{ Alternatif Strategi } \\
\hline & & \multicolumn{2}{|c|}{ Strategi I } & \multicolumn{2}{|c|}{ Strategi 2} & \multicolumn{2}{|c|}{ Strategi 3} \\
\hline & & AS & TAS & AS & TAS & AS & TAS \\
\hline \multicolumn{8}{|l|}{ Kekuatan } \\
\hline 1 Luas Lahan yang tersedia & 0.15 & 3.00 & 0.45 & 2.00 & 0.30 & 1.00 & 0.15 \\
\hline 2 Umur Petani Yang masih Produktif & 0.10 & 2.00 & 0.20 & 3.00 & 0.30 & 4.00 & 0.40 \\
\hline 3 Adanya Kelembagaan Kelompok tani & 0.05 & 2.00 & 0.10 & 4.00 & 0.20 & 3.00 & 0.15 \\
\hline $4 \begin{array}{l}\text { Kebijakan Pemerintah Daerah untuk } \\
\text { mengembangkan Ekonomi Kerakyatan }\end{array}$ & 0.10 & 4.00 & 0.40 & 3.00 & 0.30 & 2.00 & 0.20 \\
\hline 5 Tersedianya Pupuk Bersubsidi & 0.10 & 3.00 & 0.30 & 1.00 & 0.10 & 2.00 & 0.20 \\
\hline \multicolumn{8}{|l|}{ Kelemahan } \\
\hline $1 \begin{array}{l}\text { Budidaya kopi robusta yang masih } \\
\text { belum intensif dan Produktifitas rendah }\end{array}$ & 0.10 & 3.00 & 0.30 & 4.00 & 0.40 & 2.00 & 0.20 \\
\hline 2 Tingkat pendidikan petani yang rendah & 0.10 & 2.00 & 0.20 & 3.00 & 0.20 & 4.00 & 0.40 \\
\hline 3 Tingkat adopsi Iptek masih rendah & 0.05 & 3.00 & 0.15 & 2.00 & 0.10 & 4.00 & 0.20 \\
\hline 4 Akses ke modal usaha masih kurang & 0.05 & 3.00 & 0.15 & 2.00 & 0.10 & 4.00 & 0.20 \\
\hline 5 Kualitas kopi robusta masih rendah & 0.05 & 2.00 & 0.10 & 4.00 & 0.20 & 3.00 & 0.15 \\
\hline 6 Fungsi PPL belum maksimal & 0.10 & 3.00 & 0.30 & 4.00 & 0.40 & 4.00 & 0.40 \\
\hline $7 \begin{array}{l}\text { Belum terjadi jaringan kerjasama antar } \\
\text { lembaga }\end{array}$ & 0.05 & 4.00 & 0.20 & 3.00 & 0.15 & 2.00 & 0.10 \\
\hline Jumlah & 1.00 & & & & & & \\
\hline \multicolumn{8}{|l|}{ Peluang } \\
\hline 1 Perekonomian daerah dan nasional & 0.10 & 2.00 & 0.20 & 3.00 & 0.30 & 4.00 & 0.40 \\
\hline 2 Otonomi Daerah & 0.15 & 4.00 & 0.60 & 3.00 & 0.45 & 2.00 & 0.30 \\
\hline $\begin{array}{l}\text { Pasar Lokal, Domestik dan Internasional } \\
\text { Masih terbuka luas }\end{array}$ & 0.20 & 4.00 & 0.80 & 2.00 & 0.40 & 3.00 & 0.60 \\
\hline $4 \begin{array}{l}\text { Kondisi Agroklimat dan Geomorfologi } \\
\text { yang mendukung }\end{array}$ & 0.20 & 2.00 & 0.40 & 4.00 & 0.80 & 3.00 & 0.60 \\
\hline $\begin{array}{l}5 \text { Adanya Lembaga Pusat Penelitian Kopi } \\
\text { dan Kakao Indonesia di Jember }\end{array}$ & 0.15 & 4.00 & 0.60 & 2.00 & 0.30 & 3.00 & 0.45 \\
\hline \multicolumn{8}{|l|}{ Ancaman } \\
\hline $1 \begin{array}{l}\text { Sifat pasar yang terbuka mengakibatkan } \\
\text { persaingan produk dari daerah lain }\end{array}$ & 0.20 & 2.00 & 0.40 & 3.00 & 0.60 & 4.00 & 0.80 \\
\hline 2 Daya Saing yang masih lemah & 0.10 & 2.00 & 0.20 & 3.00 & 0.30 & 4.00 & 0.40 \\
\hline Jumlah & 1.00 & & 6.05 & & 6.00 & & 6.30 \\
\hline
\end{tabular}

Dari matriks QSPM di atas dapat dilihat bahwa pilihan strategi yang tepat adalah pada alternatif strategi ketiga yaitu Pembangunan Sistem Agribisnis Kopi Robusta Diarahkan Pada Peningkatan Daya Saing Melalui Pembinaan Perbaikan Mutu Dan Tampilan Produk Kopi Robusta Dan Olahannya. Dari strategi ini diharapakan nanti permasalahan utama agribisnis kopi robusta di Kabupaten Solok yaitu rendahnya kualitas beras kopi yang dihasilkan dan daya saing yang masih lemah dapat diatasi dengan kebijakan-kebijakan yang akan mendatangkan keuntungan bagi petani kopi robusta dan pembangunan ekonomi daerah Kabupaten Solok, karena pembangunan pada sektor agribisnis kopi robusta yang intensif dapat diarahkan untuk peningkatan pendapatan rumah tangga petani dan meningkatkan pertumbuhan ekonomi daerah. 


\section{SIMPULAN DAN SARAN}

\section{Simpulan}

Melalui perumusan strategi dengan menggunakan matriks SWOT sebagai tahap pencocokan strategi dan matriks QSPM sebagai tahap pengambilan keputusan strategi dapat diperoleh strategi utama dalam pengembangan agribisnis kopi robusta yaitu Pembangunan Sistem Agribisnis Kopi Robusta Diarahkan Pada Peningkatan Daya Saing Melalui Pembinaan Perbaikan Mutu Dan Tampilan Produk Kopi Robusta Dan Olahannya. Dari strategi ini diharapakan nanti permasalahan utama agribisnis kopi robusta di Kabupaten Solok yaitu rendahnya kualitas beras kopi yang dihasilkan dan daya saing yang masih lemah dapat diatasi dengan kebijakan-kebijakan yang akan mendatangkan keuntungan bagi petani kopi robusta dan pembangunan ekonomi daerah Kabupaten Solok, karena pembangunan pada sektor agribisnis kopi robusta yang intensif dapat diarahkan untuk peningkatan pendapatan rumah tangga petani dan meningkatkan pertumbuhan ekonomi daerah.

\section{Saran}

Adapun saran yang dapat direkomendasikan dalam penelitian ini adalah: 1. Kopi robusta sebagai salah satu komoditas unggulan di Kab. Solok, harus mendapatkan perhatian yang serius dari pemerintah daerah selaku pemegang kebijakan dalam sektor pembangunan.

2. Untuk dapat mengembangkan agribisnis kopi robusta di Kab. Solok, maka disarankan seluruh unsur yang terdapat dalam sistem agribisnis dapat berintegrasi.

3. Disarankan pada peneliti berikutnya yang ingin melanjutkan topik ini maka diharapkan dapat mengkaji lebih dalam masing-masing bagian dalam sistem agribisnis serta dapat mengeluarkan model pengembangan agribisnis kopi robusta.

\section{Catatan:}

Merupakan artikel dari Tesis Magister Pembangunan Wilayah dan Pedesaan PPs Unand, 2011 


\section{DAFTAR PUSTAKA}

Admaizon, 2004. Agribisnis Kopi Arabika Kabupaten Solok dengan Pendekatan Kimbun. Solok : Warta Rimbun edisi 2/2004

AEKI, 2016. Ekspor Kopi. http://www.aeki-aice.org/page/ekspor/id.

Dirjen Pengolahan dan Pemasaran Hasil Pertanian, 2007. Indonesia dan Italia

Dalam Peningkatan Peluang Kerjasama Ekspor Kopi Indonesia. Jakarta:

Departemen Pertanian.

Dirjen Perkebunan. 2014. Statistik Perkebunan Kopi Indonesia 2013- 2015. Jakarta

Kustiari, Reni. 2007. Perkembangan Pasar Kopi Dunia dan Implikasinya bagi Indonesia. Jurnal Forum penelitian Agroekonomi Vol 25 No. 1, Juli 2007 : $43-55$.

Pemerintah Daerah Kabupaten Solok. Dinas Perkebunan dan Kehutanan Kab. Solok. 2010. Statistik Perkebunan Kab. Solok Tahun 2009. Sukarami: Kabupaten Solok.

Pemerintah Daerah Kabupaten Solok. 2007. Profil Kabupaten Solok. Sukarami : Bappeda Kabupaten Solok

Rangkuti, Freddy. 2006. Analisis SWOT Teknik Membedah Kasus Bisnis. Jakarta : PT Gramedia Pustaka Utama

Swasono, S.E. 2002. Sistem ekonomi Indonesia: Makalah Seminar Pendalaman Ekonomi Rakyat, Sistem Ekonomi Indonesia. Jakarta: 19 Februari 2002

Todaro, Michael. P. 2000. Pembangunan Ekonomi Edisi Kelima. Jakarta : Bumi Aksara.

126 | Rika Hariance, Rudi Febriamansyah, dan Faidil Tanjung. Strategi .... 